\title{
Green Construction Project: A Critical Review of Retrofitting Awarded Green Buildings in Malaysia
}

\author{
F.A.Mohd-Rahim ${ }^{1 *}$, Amjad Pirotti ${ }^{1}$, Abolfazl Keshavarzsaleh ${ }^{2}$, N.Zainon ${ }^{1}$, N.Zakaria ${ }^{1}$ \\ ${ }^{1}$ Centre for Building, Construction \& Tropical Architecture (BuCTA), Faculty of Built \\ Environment, University of Malaya, Kuala Lumpur, Malaysia \\ ${ }^{2}$ International University of Malaya-Wales (IUMW), Kuala Lumpur, Malaysia. \\ *azli@um.edu.my
}

Technical-centered issues have gained far more importance in green building construction, however, the role of less technical related issues still have been left untouched or less paid attention. The project management processes and practices can contribute here and this research provides frontiers and boundaries of scope to bridge the technical and engineering areas in green building construction to project management practices and processes. Therefore, the project management researchers will have a broad view of the green building research areas. The study draws attention to investigate a position of project management, which is less associated with engineering and technology in construction, and to represent a framework based upon the case of successfully accomplished buildings. The current contribution and scope of green building, energy and project management are clarified. A semantic clustering analysis of the boundaries is implemented. 51 articles with the high impact factor (above 2.7) are selected and empirically reviewed. A literature synthesis approach is presented. Therefore, the findings are classified, and the assessment of evidence around the topics of energy scenario, green building and retrofitting, and cases of three awarded green buildings in Malaysia are facilitated. Derived from the structuralized empirical review, four core factors of retrofitting are identified: a) Energy efficiency improvement; b) Technological change; c) Organizational/managerial challenges, and d) Behavioural change. The contemplations of findings are suggested to be considered as crucial factors for every retrofitting building can be compared and discussed with respect to each of these categorized factors for enthusiast project management scholars. Green building and retrofitting of the existing green buildings have been a centre of attention for a decade. However, it appears that there is no current study which has been conducted to critically review and empirically study of previous research endeavours in order to define the frontiers and boundaries of the scope of this scientific sphere.

Keywords: Building retrofitting, Green building, Energy saving, Semantic clustering, Retrofit factors, Emission reduction

\section{INTRODUCTION}

Energy utilization and the mitigation of environmental impacts are made manifest themselves in building stock on a global scale. There is empirical evidence that existing residential buildings are represented as one of the largest greenhouse gas (GHG) emitters and heavy energy users (Jiang, Dong, Kung, \& Geng, 2013; Russell-Smith, Lepech, Fruchter, \& Meyer, 2015; UNEP, 2015; Zuo, Read, Pullen, \& Shi, 2012). Central to debate on the idea of "the significant mitigation of the environmental impacts derived from the building sector" is the question of how green building and the often associated, established performance targets and use of the word "retrofitting" are interpreted. Accordingly, green buildings not only have experienced a rapid growth lately (Kneifel, 2010; Zawawi, Kamaruzzaman, Ali, \& Sulaiman, 2010; Zhang, 2013; Zuo \& Zhao, 2014), but also have featured in a growing number of national policies with the aims of mitigating the environmental impacts and counteracting the issues connected with climate (Cook \& Khare, 2009; Kiss, Manchón, \& Neij, 2013; Li \& Shui, 2015; Nikolaou, Kolokotsa, \& Stavrakakis, 2011; Peng, Wang, \& Zhang, 2014; Poel, van Cruchten, \& Balaras, 2007). Retrofitting and constructing green building is also another solution to prevent the greenhouse gas emission and decrease the energy consumption of households. There are some researches which represent the possible methodology to retrofit and build a sustainable environment in different 
countries (Cai, Yin, \& Wennerstern, 2013; D’orazio, Di Perna, \& Di Giuseppe, 2012; Judson, Iyer-Raniga, \& Horne, 2014; Ma, Cooper, Daly, \& Ledo, 2012; Tosics, 2004; Vale, 1999; Wolfe \& Hendriks, 2011), however still there are some gaps in this field in order to achieve the most efficient retrofitting. Technical-centered issues have gained far more importance in green building construction, however, the role of less technical related issues still have been left untouched or less paid attention. The project management processes and practices can contribute here and this research provides frontiers and boundaries of scope to bridge the technical and engineering areas in green building construction to project management practices and processes.

It was in this context that, the researchers have undertaken this study based on some case studies as well as well-respected journals. This study aims at defining the frontiers and scope of the recent field of green building according to existing findings. Then a comprehensive review according to 51 studies spanning from 2006 to 2016 is reported. This introduces an innovative clustering way to ease comparison between the findings and assess the state of the art around three fundamental main topics of this research endeavor: energy scenarios, green building and retrofitting, and cases of three award winner green buildings in Malaysia. Finally, the advances and limitations to the contribution of green building context in Malaysia is discussed and provided recommendations for future research.

\section{GREEN BUILDING}

Green building and its often interpretations have gained far more importance among public, however, there are lack of clarifications that what green building stands for as well as which areas the green building should cover. The lack of crystal-clear definition leads to a schizophrenic divide among scholars which generates potential challenges for deploying and promoting the green building concept per se ( Zuo \& Zhao, 2014). In order to show the necessity for the present study, we briefly go over some papers in green building areas. This section provides an in-depth review of global practices and classifications prior to the energy scenario as a supportive factor. The green building is perceived as facilities which build in a resource-efficient manner considering environmentally-friendly based cannons so that they would be considered as healthy facilities (Kibert, 2016). More specifically, there are various sorts of green building rating/assessment tools globally, which have been developed to facilitate the development processes. The global green building rating tools are clarified geographically as the LEED (Leadership in Energy and Environmental Design) within USA context (Van der Heijden, 2015), BREEAM (BRE Environmental Assessment Method) in the UK, DGNB in Germany, CASEBEE (Comprehensive Assessment System for Built Environment Efficiency) in Japan, Green Star in Australia, GBI (Green Building Index) in Malaysia, HK BEAM (Hong Kong Built Environmental Assessment Method) in Hong Kong, PRSE (Pearl Rating System for Estidama) in United Arab Emirates and Assessment Standard for green building in China (Binglan, 2006; SCPRC, 2015). Three broad spheres are central importance in green building rating tools from micro to macro points of view, such as indoor environment, energy efficiency itself, and ecological environment. There are some factors indicate the operational performance of green buildings such as some certificates including gold-platinum and silver. Nevertheless, that fact of the matter is that to what extent these certificates are associated with higher energy efficiency. Truth to be told, the previous studies showed that by the end of 2013, a total of 1446 buildings has been certified in China since 2006, however, only 104 building went forward and obtained the operation certification, less than $8 \%$ of the whole green building stock (CSUS, 2014). Unquestionably, this gap indicates that according to the assessment of LEED, the operational excellence of goldplatinum certified buildings in terms of energy consumption should be higher than that of silver and certified projects. To state the matter differently, being certified building is not associated with having high operational excellence and having high energy efficiency in all (Turner \& Frankel, 2008). It has been clarified that the operational performance of the green building is pertinent to the orientation of green building assessment criteria (Newsham, Mancini, \& Birt, 2009; Scofield, 2013), coupled with this operation strategy and management. The scholarly studies in the green building sphere can be clustered as its definitions, scope, prospective benefits as well as the approaches to make the buildings green. However, the majority of the literature only focuses on its environmental aspects of sustainability. Therefore, there is a need to see the green building knowledge area from the lens of energy scenario whereas covers its societal and economic aspects in order to not only enable the decision-making process from the perspectives' of the end-users but also facilitate the evidence- 
based decisions by the team who conducts the project per se.

\subsection{Energy Scenarios}

Energy demand in Asia is mounting in as much as Asia's economic growth goes beyond the global average. Accordingly, it can be highlighted that energy demand and economic growth are robustly interrelated (Nikolaou et al., 2011). From a statistical standpoint, the total global final energy consumption escalated 87 percent between 1971 and 2004, comprising an average growth rate of 1.9 percent annually. Surprisingly, Asia's energy consumption was stated as 43 percent, where final consumption of energy soared 275 percent, comprising an average rate of 4.1 percent annually, which is more than twice as large as the global average.
Thus, in conclusion, the world's final energy consumption is anticipated to increase 1.5 times from 2004 to 2030. Approximately, half of that is pertinent to Asia itself, which is predicted to escalate from 27.6 percent to 35.2 percent during the same span (Hong, Chiang, Shapiro, \& Clifford, 2007). Figure 1 depicts Million Tons of Oil Equivalent (MTOE) of total final energy consumption in different countries. For example, US, China, India, Japan and some other Asian countries from 1980 to 2030 (IEEJ, 2006). It should be noted that "All Asia" encompasses the eleven Asian economies considered in this figure such as China, Japan, Taiwan, Thailand, Hong Kong, Indonesia, Philippines, India, Malaysia, Singapore and South Korea.

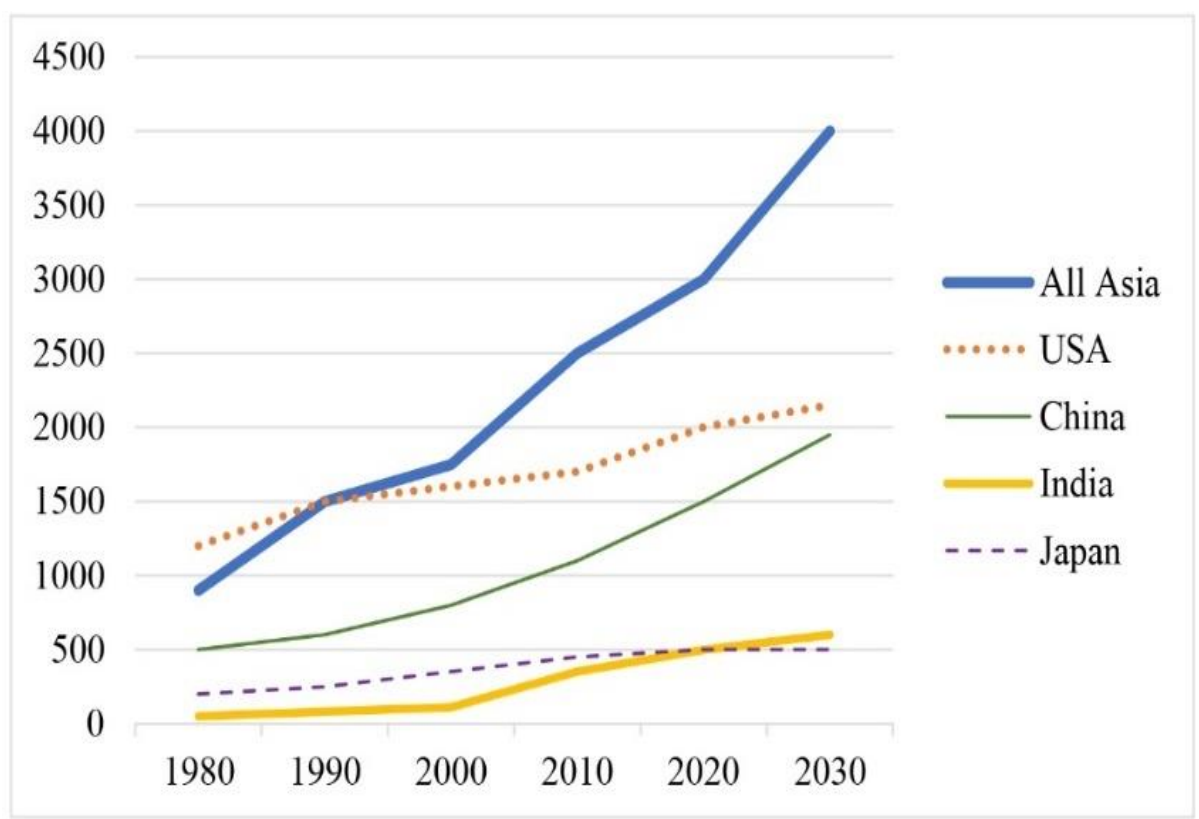

Figure 1. Total final energy consumption from 1980 to 2030 (IEEJ, 2006).

It seems certain that, with Asia's mounting economies, the built environment is increasing at an unprecedented rate, geographically. Therefore, seemingly, more than half of the globe's new buildings are built in Asia, more specifically China and India. China as the worlds' colossal construction market possesses 40 billion square meters considering existing buildings, moreover, it builds an extra two billion square meters of floor area each year, almost equal to half of the global total (Binglan,
2006). In another case, in India, the built area mounted, almost more than double between 2000 and 2005 (Swarup, 2007). Figure 2 shows the projected average annual growth rate of energy consumption for different sectors. As can be seen, the residential and commercial sector energy has emerged as a consumer of about one-third of Asia's final energy consumption in all. It should be also noted that the amount of the energy consumption in this sector is increasing (IEEJ, 2006). 


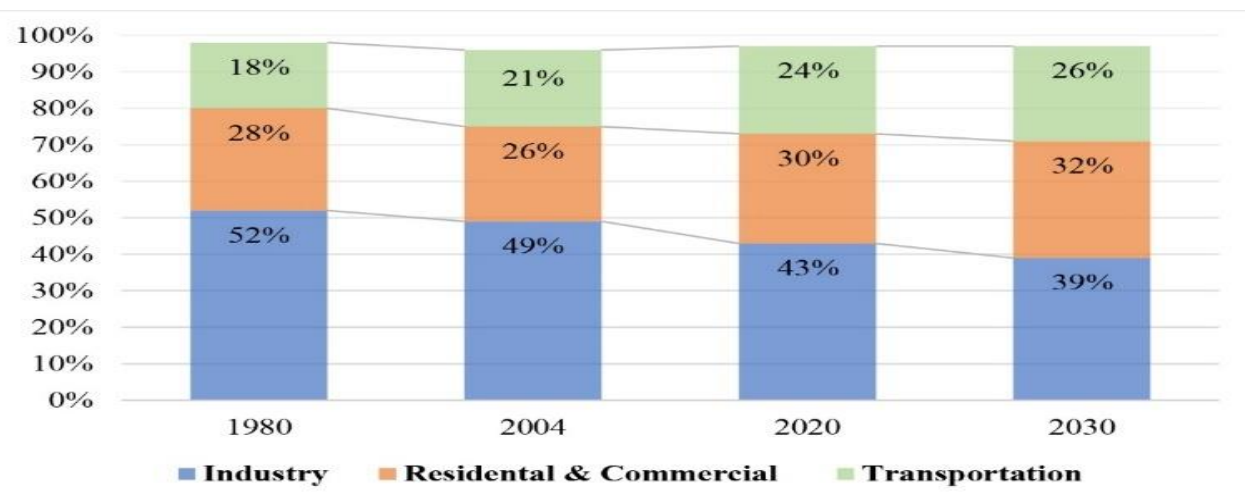

Figure 2. The projected average annual growth rate of energy consumption for different sectors in Asian countries from 2004-2030 (IEEJ, 2006).

Governments have sought the right and quickest ways to gain sustainable development of the built environment because of the worldwide effects of construction industry footprints on the ecosystem (Kneifel, 2010). Accordingly, in 2003, the directive on energy performance of buildings have been issued by the European Union, integrating a broad range of policy measures such as sales and rental transactions for the purpose of promoting energy performance of buildings and energy performance certificates for all building constructions (Recast, 2010). EU member states are obligated to wholly execute the directive until 2009. Figure 3 depicts the final energy consumption by building sectors between 1983 and 2030.

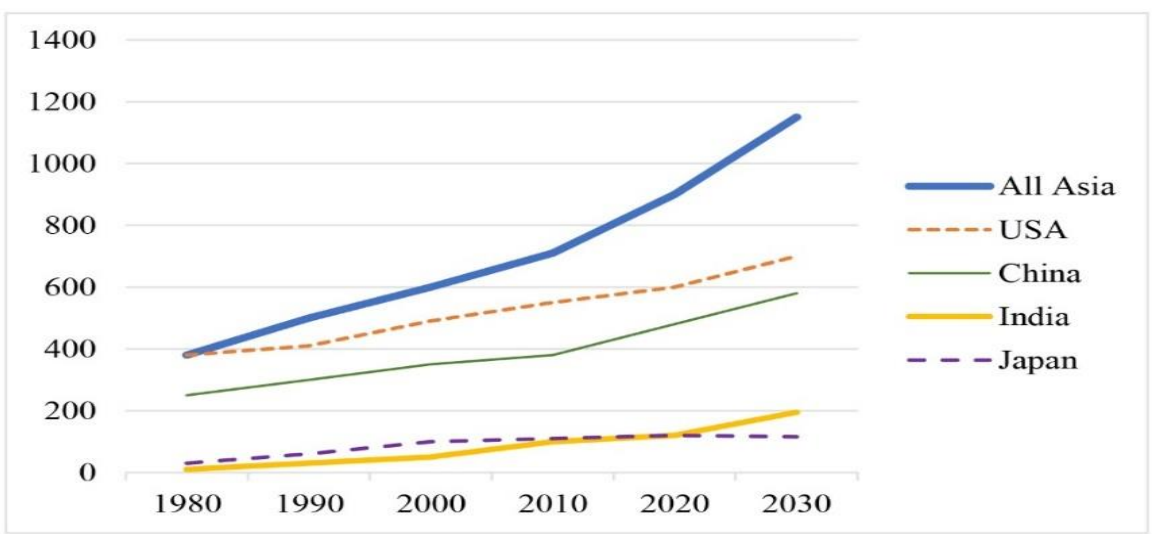

Figure 3. The final energy consumption by building sectors between 1983 to 2030 (IEEJ, 2006).

Green Building Program (GBP) was launched in 2004 by the European Commission (EC) with the aim of not only to enhance energy efficiency but also to expand the renewable energy systems' integration in nonresidential buildings, voluntarily (Hong et al., 2007). This plan drew the wide support of European Commission's intelligent energy Europe program and was established in ten European countries in a pilot phase between 2005 and 2006. In a pragmatic manner, the International Energy Agency (IEA), along with G8 countries (Highly Standardized Nations; France, Germany, Italy, UK, Japan, USA, Canada, and Russia) in 2006 engaged in initiating various programs. For example, to initiate the IEA work program on buildings in order to identify and recommend applicable policies, to establish standardized energy criteria to appraise the energy efficiency, to overview building standards which are pertinent to energy efficiency and standards in the Organization for Economic Co-operation and Development (OECD) and developing countries (IEA, 2014). Asia has been facing a looming energy crisis and plus this the need for bringing technology and modern energy access have been also intensified (Leung \& Mar, 2013). Raising living standards along with building green infrastructures are robustly tied to creativity, technology upgrade and behavioural change (Yudelson, 2010). Buildings, which account for approximately one-fourth of Asia's final energy demand are central aspects of the response to Asia's energy challenges as well (Nejat, Jomehzadeh, Taheri, Gohari, \& Majid, 2015). Green buildings and retrofitting of the existing green buildings have been prescribed 
as utmost important players. It can be said that by marring construction and design with current green building technologies and retrofitting procedures constructors and policy makers bring efficiency to energy consumption Asia's building sector. As a growing set of findings is being provided, the need for energy management, enhancement in technological advancements, and green buildings and retrofitting of the existing buildings are required than ever before.

\section{GREEN BUILDINGS AND RETROFITTING OF EXISTING BUILDINGS}

Retrofitting of the existing buildings can be more cost-effective than building a new green infrastructure. In order to deploy an appropriate retrofit, a clear return analysis of coordinated multi-component strides such as benchmarked, cased-based, fact-based, quantitatively efficient retrofit are required. This section provides an insight into the significant role of green buildings and retrofitting of the existing ones. Countries' priorities in retrofitting processes are tied to some factors such as the counties' economic level of development, resources and state of the environment in all (Li \& Colombier, 2009). There is empirical evidence that retrofitting is made manifest itself as a key player and collaborator, so that, the odds of success toward achieving the goals of green building may be increased dramatically (Bruce, Zuo, Rameezdeen, \& Pullen, 2015; Koester, Eflin, \& Vann, 2006). Therefore, there is a need for new constructions due to the wide ratio of existing buildings in order to gain greater opportunities for sustainable development (Xing, Hewitt, \& Griffiths, 2011). Many efforts have been conducted so far in terms of not only practical alterations, but also tighter energy efficiency standard stimulation within the building energy efficient retrofitting market context in the USA, Japan, and China. For example, the Chinese central government released the green building action plan, which obviously specifies the country's mission toward being green. This action plan solely focuses upon retrofitting existing building in which the total floor area of retrofitting existing buildings is planned to reach 570 million square meters by 2015 in china (SCPRC, 2015). The Chinese government, in order to pave the way, provides subsidies for the retrofitting of both buildings envelop and heating meters in existing buildings (Bao, Zhao, \& Zhu, 2012). United States of America as another leading country made accessible taxation benefits for those existing buildings that fulfill "Energy
Star" 's requirements" (Lester, 2013). In another case, Japan is made manifest its leading role within ASIAN context through encouraging the solar PV (photovoltaic) in which it is encouraged to be used in existing buildings, in which, in the sun land, the excess electricity produced from the solar PV can be stored in the grid (Chowdhury, Sumita, Islam, $\&$ Bedja, 2014). The main conclusion may be drawn from these cases is that all employed policies put the spotlight on the significance of building energy efficiency; moreover, the major role of energy efficiency should be considered when the existing buildings are being retrofitted. There is empirical evidence that the building retrofitting approaches are substantially varied. To elaborate, previous studies have focused on various aspects of ; technology (Chan, Riffat, \& Zhu, 2010; Jiang \& Tovey, 2009) including; insights from installation of renewable energy systems (Airaksinen \& Matilainen, 2011; Fiaschi, Bandinelli, \& Conti, 2012; Ishii, Tabushi, Aramaki, \& Hanaki, 2010), technical issues (Asadi, Da Silva, Antunes, \& Dias, 2012; Desmedt, Vekemans, \& Maes, 2009; Mohammadnejad, Ghazvini, \& Håkansson, 2015) during the building retrofitting comprising building envelop, and efficiency encompassing; paying attention to improving the efficiency of HVAC (heating, ventilation and air conditioning) systems (Jaffal, Ouldboukhitine, \& Belarbi, 2012; PérezLombard, Ortiz, Coronel, \& Maestre, 2011; Zhao, Zhu, \& Wu, 2009; Rao et al., 2012). It seems certain that the interaction between human and technology is of central importance in paying more attention to managerial related factors such as a systematic technique, management change (Mohareb \& Kennedy, 2014), and ultimately organization changes (Buck \& Young, 2007; Fong, Hanby, \& Chow, 2006; Masuda \& Claridge, 2014; Zhao et al., 2009). The managerial related factors are paving the way toward gaining mutually sustainable, inclusive interaction. Some of these managerial related factors are specified as policy instruments, building users' behaviour (Jiang \& Tovey, 2009) and attitude (Uihlein \& Eder, 2010), professional consultancy roles (Xu, Chan, \& Qian, 2011), and end users' perceptive (Dixon, McNamara, Miller, \& Buys, 2008) in which they are directly affect building retrofitting procedure. Other indicators which should be considered are known as; the thermal comfort level and environment quality from the technical vantage point ( Zuo \& Zhao, 2014), and the economic viability. Above all, no matter what approaches have been applied for building retrofitting, one of the most 
predominant indicators is the economic analysis of the payback period (Amstalden, Kost, Nathani, \& Imboden, 2007; Geng, Dong, Xue, \& Fu, 2012; B. Huang, Yang, Mauerhofer, \& Guo, 2012 a; Huang, Niu, \& Chung, 2012 b). There are some factors indicate the operational performance of green buildings such as some certificates including gold-platinum and silver. Nevertheless, that fact of the matter is that to what extent these certificates are associated with higher energy efficiency. Central to debate about the importance of green building retrofitting operational performance, there is a question of, what factors are interconnected to operational performance? It has been clarified that the operational performance of the green building is pertinent to the orientation of green building assessment criteria (Newsham et al., 2009; Scofield, 2013), coupled with this operation strategy and management. On the other word in order to retrofit the existing building to green building, it is required to pay attention to the governing management and strategy to exchange based on its assessment parameters.

\section{GREEN BUILDING AND PROJECT MANAGEMENT}

A critical review of existing body of knowledge regarding energy scenario, green buildings and retrofitting of the existing buildings have been revealed common focuses of these studies and where exactly they have been contributing to less technical issues. These common focuses encompass implementation and performance evaluation processes ( Zuo \& Zhao, 2014). Technical-centred issues (i.e. the technical related issues refer to the elements, which contribute to green goals such as energy efficiency) have gained far more importance in green building construction, however, the role of less technical related issues still have been left untouched or less paid attention (Wu \& Low, 2010). Related organizational and procedural barriers have been identified as major impediments for green building development and retrofitting of the existing buildings rather than innovative technological innovations (Häkkinen \& Belloni, 2011). Looking through managerial lenses, there are three managerial aspects pertinent to green buildings; project, company, and market level ( Zuo \& Zhao, 2014). The project management processes and practices can contribute here and this research provides a frontier and scope of the boundary to bridge the technical and engineering areas in green building construction to project management practices and processes. At a project level, project management tools and techniques contribute to managing green buildings construction and retrofitting of the existing buildings (Hwang \& Tan, 2012; Zuo \& Zhao, 2014). Categorized factors linked to project management of green buildings have been identified as coordination between design consultants and construction teams, support from top management and designers, technological innovation and human resource ( Li, Chen, Chew, Teo, \& Ding, 2011). For example, the study has been conducted among top green contractors in the USA whereas their project management practices on LEED projects have been identified (Ofori-Boadu, Owusu-Manu, Edwards, \& Holt, 2012) as investment on LEED, propaganda on green building development, membership of the green building council, collaborative activities with other contractors with LEED certificates, and establishing a dedicated department for green building ( Zuo \& Zhao, 2014). At company level, environmental management system implementation plays a significant role (Liu, Lau, \& Fellows, 2012). To do so, any collaborative actions between project management team and top management supports lead to increasing awareness among project team to get access to resources, which are suitable for sustainable construction (Beheiry, Chong, \& Haas, 2006; Lam, Chan, Chau, Poon, \& Chun, 2011). At market level, managerial issues are traceable considering the health of the entire green building and retrofitting of the existing building market (Love, Niedzweicki, Bullen, \& Edwards, 2011; Zuo \& Zhao, 2014). Following conclusion to be drawn from aforementioned studies that lack of project management processes and practices can be tracked in green building rating system, implementation and quality execution. Project management can offer effective and productive sets of tools/techniques/methodologies, which can be compressed as a unique package to obtain the desired aims of green building. Figure 4 depicts the elements of this package.

* Project management process in the project life cycle

* Sustainability criteria in delivering project goals

* Project construction management

* Feedback, documentation and lesson learned of the project life cycle

Figure 4. Where Project Management meets Green Building (Chu, Chang, Hwang, \& Lin, 2014; Wu \& Low, 2010). 


\section{RETROSPECTIVE EXHIBIT OF ACCOMPLISHED CASES: INSIGHTS FROM MALAYSIA}

Central to Asia's residential buildings, building energy standards were overviewed as well as upgraded through a survey; Philippines 2005, Hong Kong 2005, Singapore 1999, Thailand 2001-2005, and Malaysia in 2001. ASEAN (Association Southeast Asian Nations, including; Malaysia, Thailand, Philippines, Singapore, and Indonesia) member states have taken actions to highlight climate change through a wide range of social, economic, and environmental activities through the years. However, they are not the source of significant emission of greenhouse gases. In order to adapt to established climate targets, the majority of
ASEAN member states has launched voluntary mitigation targets, representing a decrease in ASEAN GHG emission and energy efficiency improvements to be obtained from 2020 and 2050 , respectively. To pinpoint, Indonesia has proclaimed to reduce emission by $26 \%$ from business-as-usual (BAU) by 2020, in which this amount can be heightened to $41 \%$ with international assistance; Malaysia has declared to cut down on emission of $41 \%$ regarding the energy intensity of GDP by 2020 compared to 2005 levels; the Philippines has announced to reduce emission by $20 \%$, and Singapore has claimed to reduce emission by $16 \%$ below BAU by 2020 (ACE, 2015). Figure 5 represents a chart from IEA exhibiting ASEAN growing demand of energy (IEA, 2014).

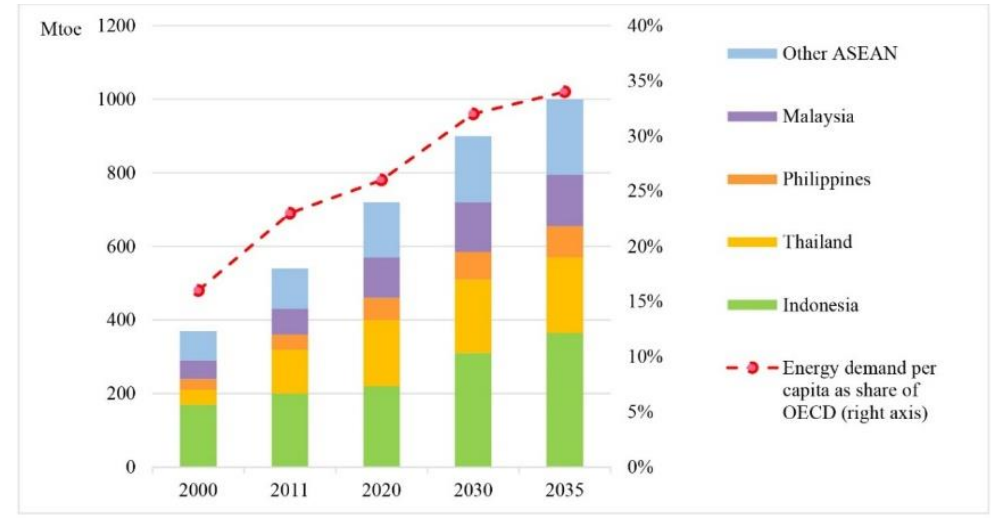

Figure 5. The energy demand of the ASEAN countries (IEEJ, 2006)

The main conclusion to be drawn from this figure indicates that these countries, collectively, accounted for $87 \%$ of ASEAN total primary energy demand in 2016, moreover, it has been projected to have a same trend until 2035. In case of Malaysia itself, this country actively engaged in transformation toward green practices through three crucial pillars (Hong et al., 2007):

- To assure the provision of secure, requisite, and cost effective supplies of energy

- To encourage and publicize the efficient use of energy; and

- To lessen the negative influences of energy production and consumption on the environment, along with promoting green energy conversion and management.

Following section covers the case study evaluation of three prominent awarded green buildings in Malaysia. This comparison highlights successes and lessons learned in managing retrofitting of the existing buildings, green buildings and energy efficiency as well.

\subsection{Awarded Green Buildings in Malaysia: Comparison}

Three awarded cases were compared and the results are tabulated in Table 1 . The LEO building, which is located in the recently built government complex of Putrajaya, is the first government building in Malaysia to be constructed with consideration of an integrated energy-efficient design. Surprisingly, the building exceeds its performance targets regarding energy saving, as the results uncovered that the actual energy savings reached 58 percent (Hong et al., 2007; KeTTHA, 2015). Using a variety of design elements along with innovative technology is of the central importance of this building. Second case, the securities commission of Malaysia is constructed in 1998 encompassing an eightstory office building. The total gross floor area is about 94,000 square meters in 1998. In addition, the third case is the Sultanah Zanariah 
Library in UTM has been retrofitted during 1993 to 1997 including a chiller load reduction, lighting retrofit, and air handling units retrofit.
The building is a four-story building with a total gross floor area of 22,500 square meters.

Table 1: Summative analysis of the awarded cases

\begin{tabular}{|c|c|c|c|}
\hline $\begin{array}{l}\text { Awarded Green Buildings } \\
\text { in Malaysia }\end{array}$ & $\begin{array}{l}\text { Low-Energy Office } \\
\text { Building (LEO) }\end{array}$ & $\begin{array}{c}\text { Securities Commission } \\
\text { Building }\end{array}$ & $\begin{array}{c}\text { Zanariah Library of the } \\
\text { Universiti Teknologi } \\
\text { Malaysia (UTM) }\end{array}$ \\
\hline $\begin{array}{l}\text { Brief Details of the } \\
\text { Awarded Green Buildings }\end{array}$ & $\begin{array}{l}\text { The building encompasses } \\
\text { six stories with a total gross } \\
\text { floor area of } 38,600 \text { square } \\
\text { meters. Its construction } \\
\text { process was finished in } 2004 \\
\text { and two years later was } \\
\text { nominated and ultimately } \\
\text { won the ASEAN energy } \\
\text { award in } 2006\end{array}$ & $\begin{array}{l}\text { The building is constructed in } \\
1998 \text { and is famous as The } \\
\text { ASEAN Energy Awards } \\
\text { Winner in } 2001 .\end{array}$ & $\begin{array}{l}\text { This project is known as a } \\
\text { retrofitted building and was } \\
\text { nominated for the ASEAN } \\
\text { Energy Award. Finally, in } \\
2001 \text { was runner-up for the } \\
\text { ASEAN Energy Award. }\end{array}$ \\
\hline $\begin{array}{l}\text { Buildings' Design Features: } \\
\text { Passive design concepts, } \\
\text { Envelopes, Orientation and } \\
\text { Lightening }\end{array}$ & $\begin{array}{l}\text { Building envelops and } \\
\text { orientation: The windows } \\
\text { are initially directed to the } \\
\text { polar-side wall where there is } \\
\text { less direct sunshine. } \\
\text { Subsequent to their most } \\
\text { efficient orientation, the } \\
\text { windows are supported by } \\
\text { suitable shading mechanisms. } \\
\text { Therefore, the transfer of } \\
\text { heat is minimized while the } \\
\text { light penetration is } \\
\text { maximized. The eastern } \\
\text { façade has featured with a bit } \\
\text { deeper shading design in } \\
\text { order to protect against the } \\
\text { low morning sun. The } \\
\text { glazing mechanisms allow } 65 \\
\text { percent of the daylight in, } \\
\text { however, keeps } 49 \text { percent of } \\
\text { the heat out. Solar heating of } \\
\text { the walls is reduced trough } \\
\text { insulation, such as the thick, } \\
\text { light-coloured walls, so that, } \\
\text { they insulate } 2.5 \text { times had } \\
\text { better than a traditional brick } \\
\text { wall. The roof, also, is } \\
\text { insulated with } 100 \text { mm of } \\
\text { insulation. A second canopy } \\
\text { roof was embedded with the } \\
\text { aim of protecting direct solar } \\
\text { radiation. Ultimately, the } \\
\text { perimeter of the roof was } \\
\text { designed with green } \\
\text { landscaping for the purpose } \\
\text { of providing shade and } \\
\text { improving the aesthetics of } \\
\text { the roof. }\end{array}$ & $\begin{array}{l}\text { Landscaping: features } \\
\text { encompass both water and } \\
\text { greenery together. There is a } \\
\text { moat that runs around the } \\
\text { building, which allows } \\
\text { natural light to light up the } \\
\text { rooms below. Moreover, an } \\
\text { irrigation room, decorative } \\
\text { lighting, soil moister meters } \\
\text { and localized shading } \\
\text { structures are embedded as } \\
\text { well. }\end{array}$ & $\begin{array}{l}\text { Lighting: the building was } \\
\text { equipped with white lamps } \\
\text { with electronic ballasts along } \\
\text { with high-efficiency } \\
\text { reflectors. This lightning } \\
\text { system once again modified } \\
\text { due to the light level was } \\
\text { found to be too high. }\end{array}$ \\
\hline $\begin{array}{l}\text { Buildings' Architectural } \\
\text { Features: Layout and } \\
\text { Design, Ventilation, } \\
\text { Roofing system and AHU } \\
\text { (Air Handling Units) }\end{array}$ & $\begin{array}{l}\text { Interior Space Layout } \\
\text { Design: the permanent } \\
\text { working areas are cantered } \\
\text { along the perimeter because } \\
\text { there is maximum daylight } \\
\text { available. The storerooms } \\
\text { and small meeting rooms are } \\
\text { concentrated where there is } \\
\text { an artificial building light. }\end{array}$ & $\begin{array}{l}\text { Roofing System: there is an } \\
\text { overhanging roof structure } \\
\text { with the aim of providing } \\
\text { shade from direct sun. There } \\
\text { is an atrium, which filters } \\
\text { natural daylight via the glass } \\
\text { roof. Ultimately, daylight is } \\
\text { maximized while energy } \\
\text { consumption is substantially } \\
\text { decreased. }\end{array}$ & $\begin{array}{l}\text { Air Handling Units: the } \\
\text { flow rates were reduced and } \\
\text { efficiency of HVAC (heating, } \\
\text { ventilation and air } \\
\text { conditioning) system was } \\
\text { increased through: replacing } \\
\text { an old massive motor with a } \\
\text { new efficient one, aligning } \\
\text { pulleys to cut down on } \\
\text { transmission losses, replacing } \\
\text { an old huge fan and motor } \\
\text { pulleys with optimally } \\
\text { designed one, adjustment of } \\
\text { over-load relay setting via an } \\
\text { electrical connection to the } \\
\text { motor and control and } \\
\text { monitoring in all. } \\
\text { Consequently, the comfort } \\
\text { level increased and total }\end{array}$ \\
\hline
\end{tabular}




\begin{tabular}{|c|c|c|c|}
\hline & & & $\begin{array}{l}\text { savings amounted to } 36.5 \\
\text { percent of the original load. }\end{array}$ \\
\hline $\begin{array}{l}\text { Buildings' architectural } \\
\text { Design: Façade and } \\
\text { Shading Design and } \\
\text { Ventilation }\end{array}$ & $\begin{array}{l}\text { Natural Air Ventilation: the } \\
\text { building was equipped with } \\
\text { atrium including four stories } \\
\text { with the aim of providing } \\
\text { daylight deep into the central } \\
\text { part of the building. } \\
\text { Moreover, a solar wall was } \\
\text { embedded at the summit of } \\
\text { the atrium, which is called, } \\
\text { "thermal flue" which is } \\
\text { providing naturally cool air. }\end{array}$ & $\begin{array}{l}\text { Façade and Shading } \\
\text { Design: high level of } \\
\text { transparency for daylight } \\
\text { obtains via double-skin } \\
\text { façade including horizontal } \\
\text { and vertical shading devices } \\
\text { with two glass layers, } \\
\text { thereby, the impact of solar } \\
\text { heat and glare is minimized. } \\
\text { The building, also, designed } \\
\text { as to reduce the amount of } \\
\text { absorbed heat through an } \\
\text { automatic blind control, a } \\
\text { ventilated air gap walkway, } \\
\text { and louvers and air exhaust } \\
\text { vent. }\end{array}$ & \\
\hline $\begin{array}{l}\text { Buildings' active design } \\
\text { features, Air Conditioning }\end{array}$ & $\begin{array}{l}\text { Air Conditioning: this } \\
\text { system has been contributing } \\
\text { to the building in an efficient } \\
\text { manner. The AC has been } \\
\text { intellectually modified as the } \\
\text { controlling system is not at } \\
\text { one central point, but it can } \\
\text { be adjusted in individual } \\
\text { rooms. Second, the AC has } \\
\text { adjusted to } 25 \text { degrees in a } \\
\text { permanent manner, which is } \\
\text { efficient based on computer } \\
\text { modelling. The finally yet } \\
\text { importantly, the Putrajaya } \\
\text { has equipped with a distinct } \\
\text { cooling plant, so the } \\
\text { receiving water is cool in this } \\
\text { area. This cooling plant } \\
\text { operates on natural gas and } \\
\text { pumps cold water via } \\
\text { pipelines, so that; there is no } \\
\text { need for individual electricity } \\
\text { air-conditioning chillers. }\end{array}$ & $\begin{array}{l}\text { Air Conditioning: includes } \\
\text { air-handling units with } \\
\text { double skin and variable- } \\
\text { speed-drive -controlled. } \\
\text { Optimum control of air } \\
\text { conditioning guarantees from } \\
\text { variable air volume and } \\
\text { terminals. Moreover, in order } \\
\text { to cool the building, the } \\
\text { system consumes less } \\
\text { amount of energy because } \\
\text { there is an under-floor } \\
\text { discharge flow in the same } \\
\text { direction as the thermal lift. }\end{array}$ & \\
\hline $\begin{array}{l}\text { Buildings' Technological } \\
\text { features: Lighting System }\end{array}$ & $\begin{array}{l}\text { Innovative Lighting } \\
\text { System: the building uses } \\
\text { high-efficiency automatic } \\
\text { lighting system, sensitive to } \\
\text { adequate daylight. The } \\
\text { building has been } \\
\text { intellectualized via } \\
\text { installation of a motion } \\
\text { detector with the aim of } \\
\text { automatically switching off } \\
\text { the lights and AC while there } \\
\text { is no physical motion within } \\
\text { the building. }\end{array}$ & $\begin{array}{l}\text { Lighting Systems: The } \\
\text { Building Automation System } \\
\text { is connected with automated } \\
\text { solar blinds, which are } \\
\text { directed via photo sensors } \\
\text { (Chow, Li, Lee, \& Lam, } \\
\text { 2013), technically. }\end{array}$ & \\
\hline $\begin{array}{l}\text { Buildings' Mechanic: } \\
\text { Ventilation, Maintenance } \\
\text { and Management }\end{array}$ & $\begin{array}{l}\text { Mechanical Ventilation: } \\
\text { there is a sensitive sensor, } \\
\text { which operates with the level } \\
\text { of } \mathrm{CO}_{2} \text {. The fact of the matter } \\
\text { is that when the more people } \\
\text { there are in the building, } \\
\text { obviously, the level of } \mathrm{CO}_{2} \text { is } \\
\text { high, and consequently, the } \\
\text { sensor will provide the } \\
\text { greater amount of fresh air. } \\
\text { Furthermore, a high-quality } \\
\text { filtration system w was } \\
\text { embedded in order to } \\
\text { increase indoor air quality. }\end{array}$ & $\begin{array}{l}\text { Management and } \\
\text { Maintenance Scheme: the } \\
\text { building is embedded by } \\
\text { computerized systems, so } \\
\text { that, the energy efficiency is } \\
\text { maximized. A high degree of } \\
\text { automation, control, and } \\
\text { management is considered } \\
\text { along with skilled staff. }\end{array}$ & \\
\hline Environmental Aspects & & $\begin{array}{l}\text { Environmental Impact } \\
\text { Consideration: } \\
\text { environmental impacts are } \\
\text { reduced through; no ozone } \\
\text { depletion refrigerants are } \\
\text { used, the low -emissivity } \\
\text { glass on the façade is not }\end{array}$ & \\
\hline
\end{tabular}




\begin{tabular}{|l|l|l|l|}
\hline & $\begin{array}{l}\text { highly reflective, a climate } \\
\text { buffer and noise pollution are } \\
\text { reduced through the double- } \\
\text { skin façade and roof plant } \\
\text { room. }\end{array}$ \\
\hline
\end{tabular}

Following analysis can be drawn from the above table that all buildings featured in designing with climates consideration with the aim of reducing the total energy consumption. Moreover, the deployments of the passive structural devices replacing the mechanical equipment are other features, which can be notified as well. The deployment of the passive structural devices along with incorporating high technologies are the robust features of the buildings which have roots in both consideration of the sustainability and proactive strategies to solve the environmental and energy conservation issues. Applications of such an advanced photovoltaic technologies are the shining examples here. In addition to the passive design features, the active design features such as using the advanced air conditioning technologies guarantee both proper ventilation and thermal comfort. Although the green building in Malaysia is pioneer and the Malaysia is introduced its green building index, but it can be said that the challenges of the construction sector in Malaysia have roots in both keeping balance between environmental, societal and economic aspects of the green building and the retrofitting of the existing ones as well as to favor the decision-making process from the perspectives' of the end-users and the project team.

\section{Lesson learned review criteria and semantic cluster analysis and discussions}

Searching keywords have been deployed within the subject-specific databases, this method is extensively popular methodology to conduct review articles (Xue, Shen, \& Ren, 2010; Yi \& Chan, 2013). To do so, specific keywords encompassing; "energy efficiency, energy and buildings and project management" were sought within the EBSCO and Science Direct databases. Following to the study objectives, the most recently published articles spanned from 2006 to 2016 were retrieved. Moreover, journals with high impact factors were considered. High impact factor can be seen as a reliable gauge in this study because mirrors the quality of the journal and its citation frequency (Hendee, Bernstein, \& Levine, 2012; Shanta, Pradhan, \& Sharma, 2013; Zupanc, 2014). Identified journals with the impact factor above 2.7 are Energy policy, Energy and buildings, Renewable energy, Energy, Renewable and sustainable energy reviews, Applied energy, Clear production, Environmental management. The methodical procedure was adopted from Kothari (2004) in which the practical, theoretical, methods and choosing an appropriate topic were articulated (see figure 6).

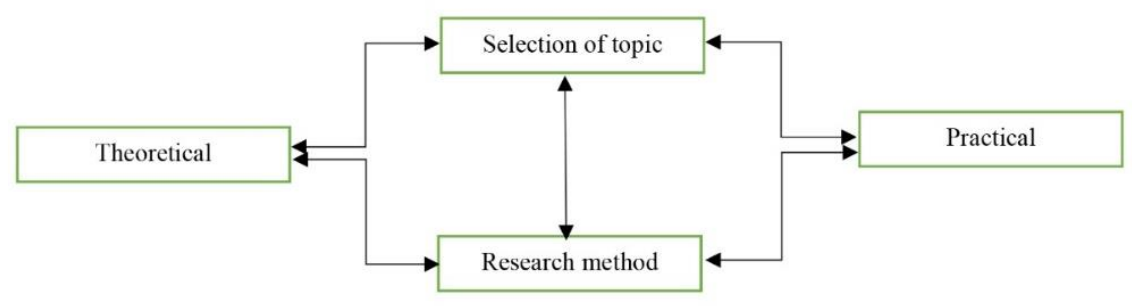

Figure 6. Research design and plan (Kothari, 2004)

Semantic cluster analysis was deployed prior to a comprehensive empirical review to define the green building frontiers in Malaysia. Semantic clustering refers to retrieving information whereas it finds lemmas/discussion topic from a given text corpus. It formalizes the degree of similarities between meanings of words via creating similarity measures/metrics which can be weighted via lexical databases (Miller, 1995). Furthermore, it computes the similarity measures/metrics, thereby; the "groups" will be shaped. The "groups" here refer to the most prominent lemmas of a "scientific discussion". In further stage, the strength of these lemmas within the specific content will be measured based on using their respective term frequency. In this study, Leximancer text-mining software was used. This text-mining software applies some sort of artificial learning algorithms, which can generate concept map. The algorithm goes through the text and generates the map 
according to word co-occurrences as well as word frequencies. This method has been approved to be both valid and reliable method of concept mapping(Smith \& Humphreys, 2006). In this study, 51 abstracts were retrieved from decisively selected sources. The reason why the abstracts were selected is the abstracts are the compressed section of every academic paper with a high lexical level of density. Prior to running the software and generating the map, precise merges between synonym terms and word variants were made. Moreover, general terms such as "research", "study" and "subjects" were excluded.

As can be seen in the concept map (see figure 7), 24 terms have identified from the abstracts and labeled as "key concepts". As it is depicted, the bubbles' size differs from one to another. The size here indicates the connectedness of the concepts to each other. The connectedness is determined by its summed co-occurrence count with all other concepts. Close position of the bubbles indicate to the extent to which the relationship between them are strong. The close position is determined by the tendency to be appeared in the similar context within the analysed source text. The following results can be drawn from the concept map; the activity themes are prominent, there is a highest coverage cross the data with 100 percent connectivity with all shown bubbles/concepts. As can be seen in this filed energy efficiency and technology, economic and building management and performance are most important factors in this field.

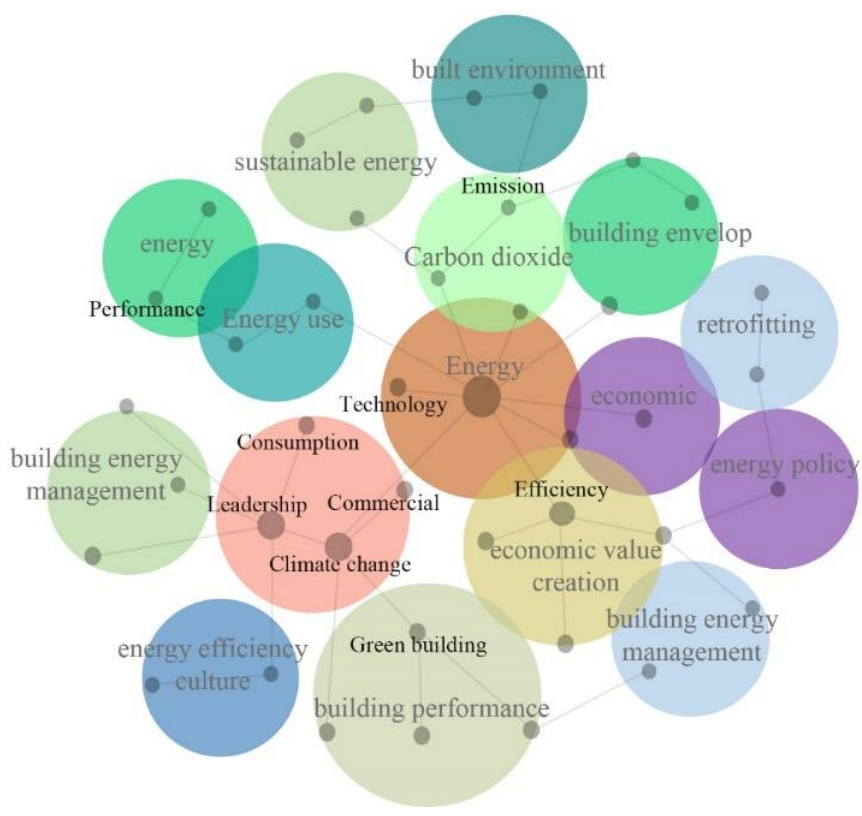

Figure 7. Concept map (Generated by Authors)

Considered to the research in this field in order to achieve the desire retrofitting of building it is required to follow some steps. The retrofitting consists of the main steps which are 1) Pre - retrofit that is includes survey analysis, scope of work \& available resources investigation, energy auditing and building performance consideration, energy saving estimation, risk assessment, economic analysis and retrofit options consideration. 2) During retrofit that in the step the retrofitting implemented and tested. 3) Post - retrofit which the post survey and measurement and test should be obtained and considered (Ma, Cooper et al. 2012).
Based on the considered previous researches in this filed and by focusing on analysing the actual contribution from current studies some consideration for retrofitting is illustrated. This will clarify the current state of empirical evidence by assisting to connect results between studies as well as allow drawing more precise boundaries of the scope of green building and energy in Malaysia. In this aim, a novel approach is proposed for the organization of green building and energy findings in order to integrate both energy and green building orientations of the field within Malaysia context. Considered to the presented cases for green buildings in Malaysia, for energy performance improvement in existing buildings 
four core categories are: a) improved energy efficiency; b) technological change; c) organizational/managerial challenge; and $\mathrm{d}$ ) behavioral change. It means for analysis and comparison a retrofitting implementation; first for the building, it is required to analysis the energy efficiency improvement by using different possible changes such as insulation of building, using multiple glazing windows etc. Then it should be considered the technological change such as lighting upgrade, energy controlling, implementing renewable energy sources etc. The next important factor is considering the organizational/managerial challenge for the retrofitted building based on the new implemented technologies and new source of energy management. Another important factor is behavioural change of the human such as changing the energy consumption pattern, used comfort equipment and activities etc.

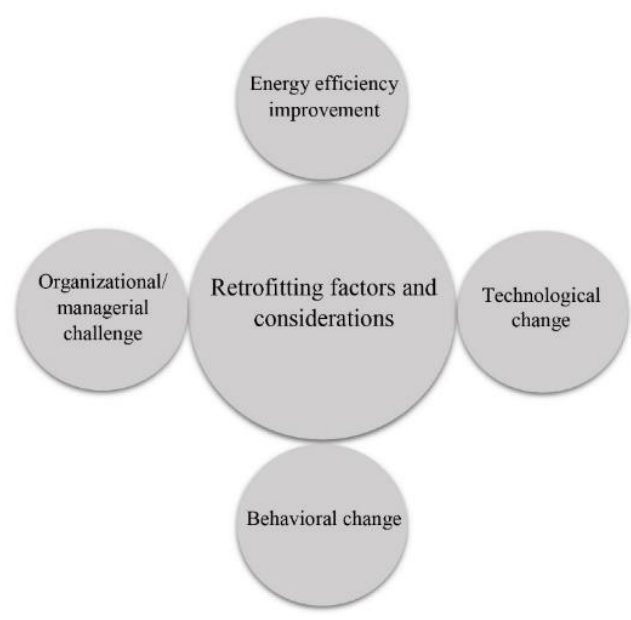

Figure 8. Suggested significate retrofitting implementing and evaluation factors (Generated by Authors)

Based on the presented factors (figure 8) each retrofitting building can be evaluated and categorized. These four main factors can be considered for any step of retrofitting such as pre-retrofit, during retrofitting and post-retrofit. It can be asserted that the true retrofitting of the existing buildings is tied to benchmarked, factbased quantitatively based energy-efficiency retrofit at the pre-retrofitting phase. The two other stages namely during retrofitting and postretrofitting are of utmost important as well considering an energy-efficiency retrofit with a crystal clear outcome/payback analysis. Figure 8 illustrates crucial factors, which should be analysed on an integrated multicomponent attempts concerning the performance guarantee of the buildings.

\section{CONCLUSION}

This study puts the spotlight on the fact that green buildings are considered as healthy facilities which build in a resource-efficient manner considering environmentally friendly and energy saving and emission reduction. In this study, three different cases in Malaysia are investigated. For implementing, the retrofitting three main steps should be considered. These steps are known as pre - retrofit, during retrofit and post - retrofit. In these steps survey analysis, scope of work \& available resources investigation, energy auditing and building performance consideration, energy saving estimation, risk assessment, economic analysis and retrofit options consideration should be considered. Based on the represented semantic clustering analysis of various research in this filed it is achieved that energy efficiency and technology, economic and building management and performance are significate factors which should be considered. As the result of this research in order to evaluate and classify the building retrofitting four main factors should be considered. The first factor is energy efficiency improvement, which should be implemented by using efficient equipment. The second factor is technological change such as using advance high technology equipment and using renewable energy sources. The third factor is organizational/managerial consideration and its challenge. The last significate factor for retrofitting evaluation and implementation is behavioural change. These represented factors lead to the most efficient retrofitting implementation. Future research puts shed light on two areas: case studies regarding project management practice and process considering the areas uncovered in the concept map "figure 7" and research in the post construction-phase considering the project life cycle.

\section{REFERENCES}

ACE. (2015). ASEAN \& Japan Move Further in Energy Efficiency Programme ASEAN \& Japan Move Further in Energy Efficiency Programme. Indonesia ASEAN Center for Energy (ACE).

Airaksinen, M., \& Matilainen, P. (2011). A carbon footprint of an office building. Energies, 4(8), 1197-1210.

Amstalden, R. W., Kost, M., Nathani, C., \& Imboden, D. M. (2007). Economic potential of energy-efficient retrofitting in the Swiss residential building sector: The effects of policy instruments and energy price 
expectations. Energy policy, 35(3), 18191829.

Asadi, E., Da Silva, M. G., Antunes, C. H., \& Dias, L. (2012). Multi-objective optimization for building retrofit strategies: a model and an application. Energy and Buildings, 44, 81-87.

Bao, L., Zhao, J., \& Zhu, N. (2012). Analysis and proposal of implementation effects of heat metering and energy efficiency retrofit of existing residential buildings in northern heating areas of China in "the 11th FiveYear Plan" period. Energy policy, 45, 521528.

Beheiry, S. M., Chong, W. K., \& Haas, C. T. (2006). Examining the business impact of owner commitment to sustainability. Journal of construction engineering and management, 132(4), 384-392.

Binglan, X. (2006). Energy standards set for buildings. China Daily, 17.

Bruce, T., Zuo, J., Rameezdeen, R., \& Pullen, S. (2015). Factors influencing the retrofitting of existing office buildings using Adelaide, South Australia as a case study. Structural Survey, 33(2), 150-166.

Buck, J., \& Young, D. (2007). The potential for energy efficiency gains in the Canadian commercial building sector: a stochastic frontier study. Energy, 32(9), 1769-1780.

Cai, Z., Yin, Y., \& Wennerstern, R. (2013). From energy efficiency to integrated sustainability in housing development in China: a case study in a hot-summer/coldwinter zone in China. Journal of Housing and the Built Environment, 28(2), 329-344.

Chan, H.-Y., Riffat, S. B., \& Zhu, J. (2010). Review of passive solar heating and cooling technologies. Renewable and Sustainable Energy Reviews, 14(2), 781-789.

Chow, S. K., Li, D. H., Lee, E. W., \& Lam, J. C. (2013). Analysis and prediction of daylighting and energy performance in atrium spaces using daylight-linked lighting controls. Applied energy, 112, 1016-1024.

Chowdhury, S., Sumita, U., Islam, A., \& Bedja, I. (2014). Importance of policy for energy system transformation: Diffusion of PV technology in Japan and Germany. Energy policy, 68, 285-293.

Chu, T. J., Chang, A. P., Hwang, C. L., \& Lin, J. D. (2014). Intelligent and Green Buildings Project Management Scope Definition Using Project Definition Rating Index (PDRI). Paper presented at the Advanced Materials Research.

Cook, P., \& Khare, A. (2009). The link between continuous commissioning and sustainable growth: a sustainable business model.
Intelligent Buildings International, 1(2), 142-155.

CSUS. (2014). Urban Studies of China. Retrieved from China:

D’orazio, M., Di Perna, C., \& Di Giuseppe, E. (2012). Green roof yearly performance: a case study in a highly insulated building under temperate climate. Energy and Buildings, 55, 439-451.

Desmedt, J., Vekemans, G., \& Maes, D. (2009). Ensuring effectiveness of information to influence household behaviour. Journal of Cleaner Production, 17(4), 455-462.

Dixon, T., McNamara, P., Miller, E., \& Buys, L. (2008). Retrofitting commercial office buildings for sustainability: tenants' perspectives. Journal of Property Investment \& Finance, 26(6), 552-561.

Fiaschi, D., Bandinelli, R., \& Conti, S. (2012). A case study for energy issues of public buildings and utilities in a small municipality: Investigation of possible improvements and integration with renewables. Applied energy, 97, 101-114.

Fong, K. F., Hanby, V. I., \& Chow, T.-T. (2006). HVAC system optimization for energy management by evolutionary programming. Energy and Buildings, 38(3), 220-231.

Geng, Y., Dong, H., Xue, B., \& Fu, J. (2012). An overview of Chinese green building standards. Sustainable Development, 20(3), 211-221.

Häkkinen, T., \& Belloni, K. (2011). Barriers and drivers for sustainable building. Building Research \& Information, 39(3), 239-255.

Hendee, W., Bernstein, M. A., \& Levine, D. (2012). Scientific journals and impact factors. Skeletal radiology, 41(2), 127-128.

Hong, W., Chiang, M. S., Shapiro, R. A., \& Clifford, M. L. (2007). Building Energy Efficiency: Why Green Buildings Are Key to Asia's Future. Asia Business Council, Hong Kong.

Huang, B., Yang, H., Mauerhofer, V., \& Guo, R. (2012 a). Sustainability assessment of low carbon technologies-case study of the building sector in China. Journal of Cleaner Production, 32, 244-250.

Huang, Y., Niu, J.-1., \& Chung, T.-m. (2012 b). Energy and carbon emission payback analysis for energy-efficient retrofitting in buildings-Overhang shading option. Energy and Buildings, 44, 94-103.

Hwang, B. G., \& Tan, J. S. (2012). Green building project management: obstacles and solutions for sustainable development. Sustainable development, 20(5), 335-349. 
IEA. (2014). Energy Outlook for South East Asia. In I. E. A. (IEA) (Ed.). France International Energy Agency (IEA).

IEEJ. (2006). Asia and World energy outlook. In T. I. o. E. E.-J. (IEEJ) (Ed.). Japan The Institute of Energy Economic-Japn (IEEJ).

Ishii, S., Tabushi, S., Aramaki, T., \& Hanaki, K. (2010). Impact of future urban form on the potential to reduce greenhouse gas emissions from residential, commercial and public buildings in Utsunomiya, Japan. Energy policy, 38(9), 4888-4896.

Jaffal, I., Ouldboukhitine, S.-E., \& Belarbi, R. (2012). A comprehensive study of the impact of green roofs on building energy performance. Renewable Energy, 43, 157164.

Jiang, P., Dong, W., Kung, Y., \& Geng, Y. (2013). Analysing co-benefits of the energy conservation and carbon reduction in China's large commercial buildings. Journal of Cleaner Production, 58, 112-120.

Jiang, P., \& Tovey, N. K. (2009). Opportunities for low carbon sustainability in large commercial buildings in China. Energy policy, 37(11), 4949-4958.

Judson, E. P., Iyer-Raniga, U., \& Horne, R. (2014). Greening heritage housing: understanding homeowners' renovation practices in Australia. Journal of Housing and the Built Environment, 29(1), 61-78.

KeTTHA. (2015). Energy and Green Technology. Malaysia: Ministry of Energy, Water and Communications.

Kibert, C. J. (2016). Sustainable construction: green building design and delivery: John Wiley \& Sons.

Kiss, B., Manchón, C. G., \& Neij, L. (2013). The role of policy instruments in supporting the development of mineral wool insulation in Germany, Sweden and the United Kingdom. Journal of Cleaner Production, 48, 187-199.

Kneifel, J. (2010). Life-cycle carbon and cost analysis of energy efficiency measures in new commercial buildings. Energy and Buildings, 42(3), 333-340.

Koester, R. J., Eflin, J., \& Vann, J. (2006). Greening of the campus: a whole-systems approach. Journal of Cleaner Production, 14(9), 769-779.

Kothari, C. R. (2004). Research methodology: Methods and techniques: New Age International.

Lam, P. T., Chan, E. H., Chau, C., Poon, C., \& Chun, K. (2011). Environmental management system vs green specifications: How do they complement each other in the construction industry? Journal of
Environmental Management, 92(3), 788795.

Lester, T. W. (2013). Dedicating new real estate transfer taxes for energy efficiency: A revenue option for scaling up Green Retrofit Programs. Energy policy, 62, 809-820.

Leung, E., \& Mar, P. (2013). Energy Efficiency in Buildings in Asia: Realizing the Untapped Opportunity. Retrieved from Fung Global Institute, Hong Kong

Li, J., \& Colombier, M. (2009). Managing carbon emissions in China through building energy efficiency. Journal of Environmental Management, 90(8), 2436-2447.

Li, J., \& Shui, B. (2015). A comprehensive analysis of building energy efficiency policies in China: status quo and development perspective. Journal of Cleaner Production, 90, 326-344.

Li, Y. Y., Chen, P.-H., Chew, D. A. S., Teo, C. C., \& Ding, R. G. (2011). Critical project management factors of AEC firms for delivering green building projects in Singapore. Journal of construction engineering and management, 137(12), 1153-1163.

Liu, A. M., Lau, W. S., \& Fellows, R. (2012). The contributions of environmental management systems towards project outcome: Case studies in Hong Kong. Architectural Engineering and Design Management, 8(3), 160-169.

Love, P. E., Niedzweicki, M., Bullen, P. A., \& Edwards, D. J. (2011). Achieving the green building council of Australia's world leadership rating in an office building in Perth. Journal of construction engineering and management, 138(5), 652-660.

Ma, Z., Cooper, P., Daly, D., \& Ledo, L. (2012). Existing building retrofits: Methodology and state-of-the-art. Energy and Buildings, 55, 889-902.

Masuda, H., \& Claridge, D. E. (2014). Statistical modeling of the building energy balance variable for screening of metered energy use in large commercial buildings. Energy and Buildings, 77, 292-303.

Miller, G. A. (1995). WordNet: a lexical database for English. Communications of the ACM, 38(11), 39-41.

Mohammadnejad, M., Ghazvini, M., \& Håkansson, L. (2015). Finite Element Modeling of Dynamic Properties of Power Supply for an Industrial Application. Paper presented at the The 22nd International Congress on Sound and Vibration (ICSV22) Italy.

Mohareb, E. A., \& Kennedy, C. A. (2014). Scenarios of technology adoption towards 
low-carbon cities. Energy policy, 66, 685693.

Nejat, P., Jomehzadeh, F., Taheri, M. M., Gohari, M., \& Majid, M. Z. A. (2015). A global review of energy consumption, $\mathrm{CO} 2$ emissions and policy in the residential sector (with an overview of the top ten $\mathrm{CO} 2$ emitting countries). Renewable and sustainable energy reviews, 43, 843-862.

Newsham, G. R., Mancini, S., \& Birt, B. J. (2009). Do LEED-certified buildings save energy? Yes, but.... Energy and Buildings, 41(8), 897-905.

Nikolaou, T., Kolokotsa, D., \& Stavrakakis, G. (2011). Review on methodologies for energy benchmarking, rating and classification of buildings. Advances in Building Energy Research, 5(1), 53-70.

Ofori-Boadu, A., Owusu-Manu, D.-G., Edwards, D., \& Holt, G. (2012). Exploration of management practices for LEED projects: Lessons from successful green building contractors. Structural Survey, 30(2), 145162.

Peng, C., Wang, L., \& Zhang, X. (2014). DeSTbased dynamic simulation and energy efficiency retrofit analysis of commercial buildings in the hot summer/cold winter zone of China: A case in Nanjing. Energy and Buildings, 78, 123-131.

Pérez-Lombard, L., Ortiz, J., Coronel, J. F., \& Maestre, I. R. (2011). A review of HVAC systems requirements in building energy regulations. Energy and Buildings, 43(2), 255-268.

Poel, B., van Cruchten, G., \& Balaras, C. A. (2007). Energy performance assessment of existing dwellings. Energy and Buildings, 39(4), 393-403.

Rao, S. P., Aminuddin, A. M. R., Thing, H. W., Jalil, N. A. A., Din, N. B. C., Manyam, N. I., \& Daud, K. (2012). Thermal and Acoustic Environmental Requirements for Green Buildings in Malaysia. Journal of Design and Built Environment, Vol. 11, No. 1, Dec. 2012. ISSN 2232-1500.

Recast, E. (2010). Directive 2010/31/EU of the European Parliament and of the Council of 19 May 2010 on the energy performance of buildings (recast). Official Journal of the European Union, 18(06), 2010.

Russell-Smith, S. V., Lepech, M. D., Fruchter, R., \& Meyer, Y. B. (2015). Sustainable target value design: integrating life cycle assessment and target value design to improve building energy and environmental performance. Journal of Cleaner Production, 88, 43-51.

Scofield, J. H. (2013). Efficacy of LEEDcertification in reducing energy consumption and greenhouse gas emission for large New York City office buildings. Energy and Buildings, 67, 517-524.

SCPRC. (2015). THE STATE COUNCIL AND THE PEOPLE'S REPUBLIC OF CHINA. Retrieved from China:

Shanta, A., Pradhan, A., \& Sharma, S. (2013). Impact factor of a scientific journal: Is it a measure of quality of research? Journal of Medical Physics, 38(4), 155.

Smith, A. E., \& Humphreys, M. S. (2006). Evaluation of unsupervised semantic mapping of natural language with Leximancer concept mapping. Behavior Research Methods, 38(2), 262-279.

Swarup, P. (2007). Indian construction industry. New Delhi, Construction Industry Development Council, New Delhi.

Tosics, I. (2004). European urban development: Sustainability and the role of housing. Journal of Housing and the Built Environment, 19(1), 67-90.

Turner, C., \& Frankel, M. (2008). Energy performance of LEED for new construction buildings. New Buildings Institute, 4, 1-42.

Uihlein, A., \& Eder, P. (2010). Policy options towards an energy efficient residential building stock in the EU-27. Energy and Buildings, 42(6), 791-798.

UNEP. (2015). Sustainable Buildings and Climate Initiative - Why Buildings. Retrieved from

Vale, L. J. (1999). The future of planned poverty: Redeveloping America's most distressed public housing projects. Journal of Housing and the Built Environment, 14(1), 13-31.

Van der Heijden, J. (2015). On the potential of voluntary environmental programmes for the built environment: a critical analysis of LEED. Journal of Housing and the Built Environment, 30(4), 553-567.

Wolfe, S., \& Hendriks, E. (2011). Building towards water efficiency: the influence of capacity and capability on innovation adoption in the Canadian home-building and resale industries. Journal of Housing and the Built Environment, 26(1), 47-72.

Wu, P., \& Low, S. P. (2010). Project management and green buildings: lessons from the rating systems. Journal of Professional Issues in Engineering Education and Practice, 136(2), 64-70.

Xing, Y., Hewitt, N., \& Griffiths, P. (2011). Zero carbon buildings refurbishment-A Hierarchical pathway. Renewable and Sustainable Energy Reviews, 15(6), 32293236.

Xu, P., Chan, E. H.-W., \& Qian, Q. K. (2011). Success factors of energy performance 
contracting (EPC) for sustainable building energy efficiency retrofit (BEER) of hotel buildings in China. Energy policy, 39(11), 7389-7398.

Xue, X., Shen, Q., \& Ren, Z. (2010). Critical review of collaborative working in construction projects: business environment and human behaviors. Journal of Management in Engineering, 26(4), 196208.

Yi, W., \& Chan, A. P. (2013). Critical review of labor productivity research in construction journals. Journal of Management in Engineering, 30(2), 214-225.

Yudelson, J. (2010). The green building revolution: Island Press.

Zawawi, E. M. A., Kamaruzzaman, S. N., Ali, A. S., \& Sulaiman, R. (2010). Assessment of building maintenance management in Malaysia: Resolving using a solution diagram. Journal of Retail \& Leisure Property, 9(4), 349-356.

Zhang, X. (2013). Going green: initiatives and technologies in Shanghai World Expo.
Renewable and Sustainable Energy Reviews, 25, 78-88.

Zhao, J., Zhu, N., \& Wu, Y. (2009). The analysis of energy consumption of a commercial building in Tianjin, China. Energy policy, 37(6), 2092-2097.

Zuo, J., Read, B., Pullen, S., \& Shi, Q. (2012). Achieving carbon neutrality in commercial building developments-Perceptions of the construction industry. Habitat International, 36(2), 278-286.

Zuo, J., \& Zhao, Z.-Y. (2014). Green building research-current status and future agenda: A review. Renewable and Sustainable Energy Reviews, 30, 271-281.

Zuo, J., \& Zhao, Z. Y. (2014). Green building researchecurrent status and future agenda: a review. Renewable and sustainable energy reviews, 30, 271-281.

Zupanc, G. K. (2014). Impact beyond the impact factor. Journal of Comparative Physiology A, 200(2), 113-116. 